\title{
Volatility Integration in Spot, Futures and Options Markets: A Regulatory Perspective
}

\author{
Shailesh Rastogi ${ }^{1,2}$ and Chaitaly Athaley ${ }^{2, *}$ \\ 1 Symbiosis Institute of Business Management (Pune), Pune 412115, India; krishnasgdas@gmail.com \\ 2 Symbiosis International, Deemed University, Pune 412115, India \\ * Correspondence: chaitaly.athaley84@gmail.com; Tel.: +91-20-2811-6041
}

Received: 30 April 2019; Accepted: 28 May 2019; Published: 9 June 2019

\begin{abstract}
The aim of this paper is to study the integration of volatility in the three markets, viz. spot, futures and options, in order to provide input for hedging purposes and the formulation of policies for derivatives. The generalized method of moments (GMM) is used to capture the simultaneous equation modelling of volatility in the three markets. The integration of the volatility in the three markets is also tested for structural breaks. The main finding of the paper is that the volatility in the options market is not associated with volatility in spot and futures market. However, volatility in spot and futures markets are associated with each other. As a consequence, investors can use options for hedging purposes and policy makers do not need to be concerned about the imminent impact of options markets on spot markets. To the best of the authors' knowledge, there is no other study which discusses the integration of volatility in the three markets. Moreover, the finding of this paper that the options market behaves differently compared to the futures market has also not been discussed in earlier studies.
\end{abstract}

Keywords: GMM; structural breaks; volatility; integration; policy initiatives

JEL Classification: G1; G2; C36

\section{Introduction}

Volatility is essentially a tool to understand the rate at which changes in price occur. The price of securities always remains centerstage for all stakeholders in the securities market all over the world. Moreover, the rate of change in the price of any security is a very important factor for researchers and industry. People across all stakeholder groups are highly interested in knowing the change in price more so than the price per se. Hence, to know the change in price in the future becomes more important than the past prices. Volatility measurement gives the impression of how the price has changed in the past. Thus, it is obvious that the future price of a security will have a bearing on the current price. However, the future price of a security may also have a bearing on the current prices of the other securities.

Understanding volatility gives a much better indication of the future prices than anything else. Therefore, investors are focused more towards knowing the volatility of a security in order to know its future prices. In the pricing of options too, the volatility of the underlying asset is one of the main inputs (Bakshi et al. 1997). Volatility in stock markets is related to the macroeconomic factors of the economy which have long-term implications (Bansal et al. 2014). Changes in volatility also raise the attention of the authorities who might decide to react to it by taking appropriate action (Han and Misra 1990). Therefore, in this paper, instead of prices, the volatility of different markets and their integration are studied.

Investing in spot markets is always preferred by investors. However, derivative markets also provide an equally lucrative but demanding platform for investments. Derivatives, as an alternative to the spot 
market, provide an opportunity to invest in the same securities, however at a lower price. Though there are varied views on investment in the derivatives market, there is enough evidence to prove that informed investors invest in derivative markets (Chen and Wang 2017; Pan and Poteshman 2006). It is also debated that informed investors may or may not invest in the futures market. Rather, it is seemingly accepted that informed investors have only two options to invest: the spot markets or the options market. This de facto acceptance does not hold water (Lin et al. 2017). Lin et al. (2017) demonstrate that investors look for opportunities to invest in futures as well as stocks and options.

As a matter of fact, derivatives markets do provide avenues to invest in securities, albeit with some additional risks, which are sweetened by the low cost of investment. However, due to regulatory concerns, all the securities listed in stock markets are normally not allowed to invest in the derivative markets. The securities which are allowed to trade in the derivatives market, in spite of their lower number, significantly impact the securities which are not allowed to trade in the derivatives market (Bologna 2000; Bologna and Cavallo 2002).

The existing studies on the three markets (the derivative markets are divided into futures and options markets; both included along with spot markets become the three markets) are performed in the following ways. The first set of studies are performed on any two markets out of the three (Chakravarty et al. 2004; Chan 1993; Chan et al. 1991, 2002). The second set of studies are on all the three markets together, but mainly focus upon the lead-lag relationship between prices or returns (Jong and Donders 1998). However, neither of these study methods address the issues of studying volatility in all the three markets together.

Atilgan et al. (2016) exhibit in a survey on derivatives that studies are mostly performed on price discovery, market structure and market efficiency. Moreover, studies are mainly performed on Taiwan, Korean and Chinese markets. Only few studies have been carried out on pricing and risk management in the derivatives market, and for that matter, on developed economies. Studies on volatility in the Indian derivatives market are rare. There are a few studies on implied volatility and realized volatility (Ryu 2012; Szu et al. 2011). At the most, Han and Misra (1990) claim that in the absence of transaction costs and corporate action, volatility in all the three markets should be the same for stock indices as the underlying security. However, studies on the integration of volatility in all the three markets remain non-existent. This paper fills this research gap to ensure both novelty and contribution to the field.

There are many studies which link spot market volatility with the volume in the options market (Chen and Wang 2017; Sarwar 2005). Likewise, there are a few studies on how volume in the futures market is linked with the volatility in the spot markets (Bessembinder and Seguin 1992). On the contrary, the present paper studies the association among the volatility present in all three markets together.

Structural breaks, while studying volatility in the securities market, are a well-researched phenomenon (Banerjee and Urga 2005; Fernandez 2004; Morales-Zumaquero and Sosvilla-Rivero 2010; Morales and Gassie-Falzone 2014; De Davide 2018). Two possible structural breaks are identified during the time-period undertaken for the present study. The first break is in India in May 2014 when a major political and economic change took place. The second break is identified when the same change in political set-up took place in the USA in November 2016. The second break becomes more significant because during the same time period, a demonetization exercise was executed in India. Both structural breaks are part of the present study.

The research objectives of the paper are as follows:

1. To analyze the long-term association of volatility in all three markets (spot, futures and options)

2. To compare the integration of volatility before and after both structural breaks (May 2014 and December 2016) undertaken in the study.

The remainder of the paper is arranged in the following manner. The introduction is followed by the second section which includes a literature review. The third section demonstrates the data and methodology used, followed by the fourth section where empirical results are presented. A discussion 
and conclusion of results is presented in the fifth section. The author's contribution is the sixth and last section of the paper.

\section{Review of Literature}

The literature is replete with studies on volatility under different situations, such as the spot, futures and options markets. A discussion on the review of literature pertinent to this paper is performed in the context of the following areas: (1) spot and futures markets; (2) spot and options markets; (3) futures and options; and (4) spot, futures and options markets.

The integration of the futures market with the spot market is one of the most relevant areas of this paper. Though there are studies between these two markets, only a few discuss the integration of volatility in both markets (Bessembinder and Seguin 1992; Chan et al. 2018; Chang et al. 2017; Qin et al. 2018). Most of the studies are on prices, returns, and price discovery in one market caused by the other markets. He and Xie (2012) show that in China, the futures price leads the spot market for price discovery. In the crude oil market, futures contribute to price discovery in the spot market (Silverio and Szklo 2012). In the Turkish stock market, a significant association between the futures and spot markets is reported (Kasman and Kasman 2008). It is common to study spot market prices either with the futures market or with the forwards market (Kavussanos and Visvikis 2004; Kavussanos et al. 2014). Kim and Ryu (2014) show that the futures market impacts more upon the volatility of the spot market than on the return or the volume of the spot market. On the contrary, Judge and Reancharoen (2014) find evidence that in Thailand, market change in the spot market leads to changes in the futures market.

Huo and Ahmed (2017) document the volatility spillover effect from the futures market to spot markets in China. There are studies that highlight the impact of the introduction of futures on spot volatility and a resultant increase in market efficiency in the spot market (Bae et al. 2004). The mixed results of the impact on spot volatility due to the introduction of futures is reported (Xie and Mo 2014; Yu 2001). Pok and Poshakwale (2004) show that the introduction of futures increases the volatility in spot markets in the Kuala Lumpur stock exchange. Through an earlier study, Edwards (1988) advocates that there was no impact due to the introduction of index futures on stock index volatility. Bologna (2000) finds evidence in the Italian market that the introduction of futures does not change the nature of volatility in the spot market, however, volatility does slow down due to the introduction of futures. Moreover, it is also evinced that volatility is inversely proportional to the trading volume of futures. Koutmos and Tucker (1996) show an association of volatility in the spot and futures markets; they highlight that the futures markets volatility takes lead over spot market volatility.

Chan et al. (1991) posit that there is interdependence between the volatility of spot and futures markets. Darrat et al. (2002) exhibit that spot market volatility does impact the futures volatility but the opposite (futures volatility impacting the spot market volatility) is not true. Hodgson and Nicholls (1991) highlight the positive correlation between the volatility of futures and spot markets. Tokat and Tokat (2010) highlight the interdependence of the volatility of futures and spot markets in the Turkish stock exchange. Chang et al. (2018) discuss the integration between the futures markets of exchange traded funds (ETFs) and the energy and financial markets.

There are several studies which show the association between spot and options markets. Guo and Qiu (2014) demonstrate a negative association between option induced volatility measures (variance) and returns in the spot markets. There is evidence to claim that price discovery in spot markets is due to the options market (Hentze and Seiler 2000). Li (2008) demonstrates that until a certain level in the option prices, there is no impact on the volatility of the underlying asset. However, as the threshold is crossed, the option prices go up, beyond the threshold, the arbitrage is increased, and consequently, the volatility in the spot markets goes down. In a lead-lag relationship between the options and spot markets, the spot markets take the lead over options markets (Stephan and Whaley 1990). Turkington and Walsh (2000) posit that spot prices lead option prices but the volume observed in the spot markets leads prices in both the spot and options markets. 
Relatively less literature is found on the association of volatility in the three markets (spot, futures and options markets) as more attention is given to any of the two markets than the three markets altogether. In some of the early works on futures and options markets, Draper and Fung (2002) find evidence of profitable arbitrage opportunities due to futures and options markets. Later on, Fahlenbrach and Sandås (2009) show evidence of a co-movement in prices of options and futures. They use the FTSE 100 index options and futures (The Financial Times Stock Exchange 100 Index) to highlight the co-movement of the prices. Despite the significant evidence of the co-movement of prices, studies on the association between volatility in both the markets (futures and options markets) are quite rare. After many years, Farkas et al. (2017) evince a significant co-integration among the prices of futures and options markets for ten commodities. In addition to this, Lin et al. (2017) document the impact of index option trading on index futures. However, none of the studies on options and futures markets discuss the association of volatility in both the markets.

There are very few studies on the three markets altogether. One of the earlier works is by Kleidon and Whaley (1992) who show how the three markets fared before and after the financial crisis of 1987. Pericli and Koutmos (1997) examine the impact of the currency derivatives market on spot volatility. They showed that in normal conditions derivatives do not impact the spot markets. However, they report a significant impact of derivatives on the spot market due to extreme events, for example the financial crisis of 1987. Jong and Donders (1998) use the European options market data of 1992-1993 to show that the futures market takes lead over the spot and options markets in terms of price discovery. This was a surprising result because the futures market usually does not take lead among the three markets. In another similar study on the lead-lag among the three markets in Hong Kong (Chiang and Fong 2001), it is found that the spot market takes the lead over the other two markets. Kang et al. (2006) posit the association among the three markets and find evidence that the options market leads the futures market and the futures market leads the spot market.

Debasish (2009), while studying Indian spot, futures and options markets, evinces that derivatives take lead over the spot markets. However, between the futures and options markets, for calls, options lead over futures whereas in the case of puts, futures take the lead. However, all of these studies do not deliberate upon the association among volatility in spot, futures and options markets. Shenbagaraman (2003) documents that the introduction of options and futures in India does not bring much change in the volatility of the spot market. Only the nature of the volatility is changed due to the presence of derivatives (some impact on the persistence and reactivity of the volatility are reported). In a UK study on the FTSE 100, it is demonstrated that in the normal course, derivatives do not impact the spot market. However, during some specific periods of exigency, spot volatility is impacted by the derivatives market. Wang and Chen (2007) exhibit a unidirectional spillover from the futures market to the options market and a bidirectional spillover between the spot and futures markets in the Taiwan Stock exchange.

Chan and Lien (2006) study the three markets for currency. They argue that currency options reduce the interdependence between the spot and futures markets, and hence the options market dominates among the three markets. Chen and Gau (2009) do find evidence of the association among the three markets, but for returns and not for volatility. Chang et al. (2010) examine changes in the volatility of the spot market due to the options and futures markets. They highlight that there is no impact on the volatility of the spot market due to the options and futures markets.

There are studies on the three markets which discuss volatility, but only in one of the three markets (Bollen and Whaley 2004; Chen and Wang 2017; Ni et al. 2008; Sarwar 2005). It is observed that spot volatility integration is linked only with the volatility of the options market, not with the volatility of the futures market. It seems as if they are oblivious to the fact that there is a futures market where informed traders can also take positions, which may impact the volatility in the spot market. However, to the best of our knowledge, no other study discusses about the role of futures market on the volatility in the spot market. Cheng et al. (2000) evince that a discussion of spot market volatility is incomplete without considering the futures market along with options market. However, we believe that the present work is pioneering in that it explores the volatility of the futures market 
along with spot and options markets. The present study fills the gap created by the absence of the futures markets in studying volatility amongst these three markets. Additionally, the present study investigates the association among the volatilities of the three markets, viz. spot, futures and options markets. With reference to the abovementioned discussion in the literature review, the following hypotheses are proposed for empirical testing:

Hypothesis 1. The volatility of all three markets studied have a long-term association.

There is enough literature to support the significant structural breaks in the volatility series. Fernandez (2004) explores structural breaks in volatility using two approaches: ICSS (Interactive cumulative sum of squares) and wavelet analysis. Dufour and Ghysels (1996), in their earlier work on structural breaks, examine where and how studies on structural breaks are performed using econometric modeling. Banerjee and Urga (2005) exhibit the instances of econometric modelling for structural breaks in long-memory volatility and the co-integration among volatility. Morales-Zumaquero and Sosvilla-Rivero (2010), in a study on the volatility of foreign exchange, find evidence of structural breaks. Morales and Gassie-Falzone (2014) also demonstrate instances of structural breaks while studying the volatility spillover between crude-oil markets and stock markets. The following hypothesis is formulated based on the above arguments:

Hypothesis 2. The degree of association of volatility in the three markets changes during the time-periods separated by structural breaks.

\section{Data and Methodology}

\subsection{Data}

For spot rates, weekly closing prices of the Nifty-50 (index of the National Stock Exchange, India) are collected for between 2010 and 2017. For futures, weekly closing prices of Nifty-50 index-futures are taken, and for options, weekly closing prices of Nifty-50 index-options are taken from 2010 through 2017 (Wang and Wu 2013). The prices have been obtained from the official website of NSE (National Stock Exchange). Hu (2014), the prices of five days or less, and before expiry are discarded. Both index options and index futures are traded for three months on NSE (National Stock Exchange). In addition to reducing expiry effect, for rollover of the options before expiry, the 5-day time period is applied (Chiang and Fong 2001). Bothfutures and options on the Nifty-50 index, expire every three months. Therefore, to get a continuous series for futures, as well as for options, the assumption of rollover of Nifty-index futures and options is applied in this paper (Floros and Salvador 2016).

The literature supports the view that at-the-money (ATM) options give a more accurate estimate of volatility than out-of-the-money (OTM) and in-the-money (ITM) options (Gemmill 1986; Gwilym and Buckle 2001). Options priced at less than $\$ 1$ are removed in order to avoid minimum tick bias (Han and Misra 1990). The same approach is used in the current paper for collecting options prices.

\subsection{Summary Statistics}

The closing prices from all the three markets are gathered. These price series are converted into return series. Further, the GARCH $(1,1)$ model (Generalized Autoregressive Conditional Heteroscedasticity) is applied on the return series in order to generate a variance series for all three markets, viz. spot, futures and options markets (index, index-futures, index-call options and index-put options respectively). Descriptive statistics of all the four variance series are reported in Table 1 . The mean variance for index and index-futures are quite low at $0.04 \%$ and $0.05 \%$ respectively. The same is true for the standard deviation of the variance series for both. However, in the case of options, the mean variance is $24.72 \%$ and $22.32 \%$ for call and put options, respectively. 
Table 1. Descriptive.

\begin{tabular}{ccccc}
\hline Variables (at Levels) & Observations & Mean (\%) & Standard Deviation (\%) & JB Statistics ${ }^{\circledR}$ \\
\hline$h s$ (Index) & 411 & 0.04 & 0.02 & $380.54^{*}$ \\
$h f$ (index futures) & 411 & 0.05 & 0.01 & $521.98^{*}$ \\
$h_{o c}$ (index call option) & 411 & 24.72 & 3.63 & $451.61^{*}$ \\
$h_{o p}$ (index put option) & 411 & 22.32 & 2.14 & $625.83^{*}$ \\
\hline
\end{tabular}

Notes: 1. Weekly data is collected. Closing prices on the last working day of the week has been taken. 2. GARCH $(1,1)$ model is used for estimating variance. 3. Variance of the return series is calculated. 4. As explained by JB statistics, no variance series is normally distributed. $5 . h s$ is variance of return series of Index. $h f$ is variance series of return of index futures. $h_{o c}$ and $h_{o p}$ are variance series of return of index call and index put respectively. ${ }^{\circledR}$ Null of normalcy is tested by JB test (Jarque Bera Test) (Jarque and Bera 1980). * Significant at $5 \%$ level.

All the four variance series are not-normal as the JB test statistics (Jarque Bera Test) result is significant in all four cases. In addition to descriptive statistics, the stationarity of all four variance series is tested using the augmented Dickey Fuller (ADF) test and Phillips-Perron (P-P) tests. All four variance series are stationary at levels (Table 2).

Table 2. Test of Stationarity.

\begin{tabular}{ccc}
\hline Variables (at Levels) & ADF (Augmented Dickey Fuller Test) & P-P Test (Phillips and Perron Test) \\
\hline$h s$ (Index) & $-2.9428^{*}$ & $-3.0406^{*}$ \\
$h f$ (index futures) & $-3.0754^{*}$ & $-3.1992^{*}$ \\
$h_{o c}$ (index call option) & $-12.3959^{*}$ & $-6.4287^{*}$ \\
$h_{o p}$ (index put option) & $-20.6062 *$ & $-19.7671^{*}$ \\
\hline
\end{tabular}

Notes: 1. Null of non-stationarity is tested by ADF test (Dickey and Fuller 1979, 1981) and P-P test (Phillips and Perron 1988). Level of significance is at $5 \%$ in both the tests; $2 .{ }^{*}$ Test result is significant at $5 \%$ level of significance. All four variance series are stationary at levels.

\subsection{Methodology}

The stationarity of the time series is tested by using the augmented Dickey-Fuller test and P-P test (Phillips and Perron 1988). Following the law of parsimony, the optimum lag length is selected on the basis of AIC (Akaike information criteria) and SCI (Schwartz's information criteria). On preliminary investigation of the data, it is established that the price series of spots and futures are non-stationary at levels, but options price data is stationary at levels. This was uniquely present in the context of the Indian index option market because normally index-options are also non-stationary at levels (Turkington and Walsh 2000).

The possibility of co-integration among the volatility of the three markets is ruled out because the variance series of all three markets is stationary at levels. There are many studies where co-integration among the three markets is studied. However, most such studies are not on the volatility, but on the prices or returns (Sogiakas and Karathanassis 2015). The present study is on the volatility of the three markets and their long-term association. However, the possibility of studying co-integration is ruled out because the volatility series (variances) of the three markets are stationary at levels, which is the primary violation of co-integration, as discussed earlier. Furthermore, as the authors want to establish a long-term association among the volatility of the three markets, the volatility spillover effect is also left unexplained (Malhotra and Sharma 2016) (volatility spillover effect among the volatilities of three markets can be a future area of study on this topic).

As a consequence, having explored and ruled out the possibilities of co-integration and the spillover effect, the authors aimed to use regression. However, as the literature supports simultaneity in the three markets, the current study also tests for simultaneity among the volatility of the three markets. The volatility spillover effect also corroborates the existence of simultaneity among the volatility of all the three markets (Malhotra and Sharma 2016; Wang and Chen 2007). Therefore, the systems of equation should be the obvious choice for studying the volatility in the three markets, 
provided simultaneity is tested positive (Simultaneity can be tested with the help of the Hausman test for simultaneity).

There are a few methods that can be used to study simultaneous equations. Because studying contemporaneous effects is a part of one of the objectives of the study, the VAR (vector auto regressive) method has not been used. Between TSLS (two-stage least square) and GMM (generalized method of moments), the present study has applied GMM. The optimum least square (OLS) including TSLS, and ML (maximum likelihood) methods have the following limitations: (1) the model should be specified; (2) linearity assumption should hold true; and (3) distributional assumption is supposed to take care of autocorrelation and heteroscedasticity (Jagannathan et al. 2002). The GMM method handles the abovementioned limitations well; therefore, between TSLS and GMM, the authors preferred the GMM method in the current study.

The instrumental variable method is a standard method used to handle cases of simultaneity among TSLS, GMM or LIML (limited information maximum likelihood) (Larcker and Rusticus 2010). The same is also applied in the present study.

In general, there is abundant literature for the world markets, and in particular for the Indian market, that supports the GARCH $(1,1)$ model's ability to give a better estimate of volatility than the other models (Andersen and Bollerslev 1998; Karmakar 2005; Rastogi and Srivastava 2011). However, there are some exceptions for the choice of the $\operatorname{GARCH}(1,1)$ model as the best model to estimate volatility (Gabriel 2012). Despite the exceptions, for this study on the Indian market, due to the literature support, the $\operatorname{GARCH}(1,1)$ model is applied to estimate the variance series (volatility) for all the three markets undertaken in the current study.

\subsection{The Econometric Model and Contemporaneous Relationship}

The following system of equations is estimated using the GMM estimator. All the three volatility measures have been treated as endogenous variables. Lag terms of all the endogenous variables are treated as instrument variables (IV) because the lag of endogenous as well as exogenous variables are predetermined variables. Predetermined variables are exogenous in nature. Weekly data has been taken; therefore, only one lag has been considered in the following equations for endogenous variables:

$$
\begin{aligned}
& h_{S t}=\alpha_{0}+\alpha_{1} h_{s t-1}+\alpha_{2} h_{f t}+\alpha_{3} h_{f t-1}+\alpha_{4} h_{o t}+\alpha_{5} h_{o t-1} \\
& h_{f t}=\beta_{0}+\beta_{1} h_{f t-1}+\beta_{2} h_{s t}+\beta_{3} h_{s t-1}+\beta_{4} h_{o t}+\beta_{5} h_{o t-1} \\
& h_{o t}=\gamma_{0}+\gamma_{1} h_{o t-1}+\gamma_{2} h_{f t}+\alpha_{3} h_{f t-1}+\alpha_{4} h_{s t}+\alpha_{5} h_{s t-1}
\end{aligned}
$$

where

$h s$ - volatility of index

$h f$-volatility of index futures

$h_{0}$-volatility of index options (call and put both; for call $h_{o}=h_{o c}$ and for put $h_{o p}$ ).

The three equations (models) applied in this paper also test the contemporaneous effect on the volatility of one market due to the volatility of the other markets. This is also one of the reasons to use the GMM rather than the VAR (vector autoregressive) model. But for testing predictability in the models, we need to use the lag terms (Sarwar 2005). This study restricts itself to only two lags as the scope of the paper is to study integration of volatility in spot, futures and options markets. Studying predictability can be a future area of study and higher lag terms could be tested. Presence of lag terms in the equation as exogenous variables serve two purposes. First, they help in testing the predictability of the dependent variable due to the lag terms of the variable(s) and second, they work as instrument variables in the estimation of equations. Insignificant $j$-statistics and Cragg-Donald statistics confirm the proper identification of the model and strength of the lagged variables as instruments. 


\subsection{Structural Breaks}

Indian markets have witnessed two extreme events, which bring policy change as well as a disruption in the Indian economy, during the time period of the study (2010-2017). In May 2014, the political leadership changed in India. The second upheaval was observed when the same change of guard took place in the USA in November 2016. These two points of intervention are considered as structural breaks to investigate further. The GMM breakpoint test is applied to verify the possibility of structural breaks on the abovementioned years.

\section{Results}

Empirical testing is reported at three levels.

\subsection{Endogeneity}

Endogeneity is tested in all the four cases (Equation (3) is estimated two times; one for call-options and the second for put-options). The Durbin-Wu-Hausman test is conducted on each regression equation (Equations (1)-(3)). The Durbin-Wu-Hausman test is for the null hypothesis of OLS to be consistent and an efficient estimator. In other words, for the Durbin-Wu-Hausman test, the target variables are assumed to be exogenous in the null hypothesis. The result of the tests is reported in Table 3. In the first case of the variance series with the index as dependent variables, index futures and call options have been tested for endogeneity. Similarly, in the second case of index-futures as the dependent variable, index and index-call options are tested for endogeneity. In the case of index-call option as the dependent variable, index-spot and index-futures are tested for endogeneity. Likewise, in the fourth case of index-put-options as the dependent variable, index-spot and index-futures are tested for endogeneity (Table 3).

Table 3. Regression Analysis results-GMM (Generalized method of moments).

\begin{tabular}{|c|c|c|c|c|}
\hline Dependent Variable & $\begin{array}{c}h_{s} \\
\text { (Index) }\end{array}$ & $\begin{array}{c}h_{f} \\
\text { (Index Futures) }\end{array}$ & $\begin{array}{c}h_{o c} \\
\text { (Index Call Option) }\end{array}$ & $\begin{array}{c}h_{o p} \\
\text { (Index Put Option) }\end{array}$ \\
\hline$h_{S}$ & & 1.1939 * & 6792.21 & -336.5040 \\
\hline$h_{s-1}$ & $0.9271 *$ & $-1.1067^{*}$ & -6347.18 & 303.4835 \\
\hline$h_{f}$ & $0.8342 *$ & & -5834.384 & 298.5364 \\
\hline$h_{f-1}$ & $-0.7706^{*}$ & 0.9237 * & 5432.77 & -266.4965 \\
\hline$h_{o c}$ & 0.0000 & 0.0000 & & \\
\hline $\begin{array}{c}h_{o c-1} \\
h_{o p}\end{array}$ & 0.0000 & 0.0000 & 0.6859 & \\
\hline$h_{o p-1}$ & & & & $0.8086^{*}$ \\
\hline J-Statistics & 0.1156 & 0.1194 & 0.4807 & $4.0438 *$ \\
\hline $\begin{array}{c}\text { Endogeneity test } \\
\text { (Durbin-wu-Hausman test) }\end{array}$ & 1.0201 & 1.3466 & $7.7291 *$ & 0.5921 \\
\hline $\begin{array}{l}\text { Weak Instrument Diagnostic } \\
\text { (Cragg-Donald Statistics) }\end{array}$ & 0.2601 & 0.1916 & 0.0390 & 0.1049 \\
\hline GMM Breakpoint Test (May 2014) & 1.5491 & 4.1687 & $12.7659 *$ & 3.8294 \\
\hline GMM Breakpoint (November 2016) & $58.1998 *$ & 83.1618 * & $57.8215 *$ & $32.2301 *$ \\
\hline
\end{tabular}

Notes: 1. Instrument variables are same for all the four endogenous models. They are $h_{s-1}, h_{s-2}, h_{f-1}, h_{f-2}, h_{o c-1}$ and $h_{o c-2}$. Constant term is part of the Instrument list by default. 2. J-statistics is for identification of the equation. Null hypothesis for J-statistics is appropriateness of identification of the regression equation using GMM. Null of Endogeneity test is that OLS is consistent and efficient estimator. Null of weak instrument diagnostic in that instruments are not weak. The critical value for Cragg-Donald statistics at $10 \%$ is 13.43 . Null of GMM breakpoint test is no breakpoint. ${ }^{*}$ Significant at $5 \%$ level.

Out of the four Durbin-Wu-Hausman tests, only in the case of the index-call option as the dependent variable is the test significant. This implies that endogeneity exists among the index-call-option, index-spot and index-futures. However, index-put-options have not shown endogeneity with any of the other three variables into consideration. 


\subsection{Long-Term Association among Volatility of Spot, Futures and Option Markets}

Equations (1)-(3) are empirically tested using the GMM as estimator. Results of the estimated models have been reported in Table 3. Index-spot variance is regressed on the five variables considered as exogenous for this equation: one lag of index-spot variance, at the level of index-future variance, at one lag of index-future variance, at the level of index-call-option variance and at one lag of index-call-options variance. The volatility (variance) of index-spot has a long-term significant relationship with the volatility (variance) of index-futures, but an insignificant relationship with the variance series of the index-call option. This mean volatility of index-spot is related to the volatility of index-futures, but not to the volatility of index-options. Besides this, Equation (1) (index-spot as dependent variable) is properly identified as J-statistics is 0.1156 and insignificant (null of appropriateness of instruments for identification cannot be rejected). Further, Cragg-Donald statistics is insignificant for Equation (1), implying the instruments are strong enough to be used in the given specification.

A similar estimation of index-future as the dependent variable (Equation (2)) is significant for index-spot (both level and one-lag) but insignificant for index-call-options. Therefore, the volatility of index-futures has a long-term association with the volatility of index-spot, but not with the volatility of index-call-options. Further, this relationship, also properly identified as $j$-statistics for this equation (Equation (2)), is insignificant. In addition to this, a weak instrument diagnostic test is also insignificant. This signifies that the instruments are strong enough to estimate this relationship in Equation (2) (Table 3).

The results for the variances of index-call and index-put-options as dependent variables (Equation (3) are also reported in Table 3. The variance of the index-call-option as a dependent variable does not have a significant association with the variances of index-spot and index-futures. This means that index-call-option volatility does not have any long-term association with the volatility of index-spot or index-futures; however, the identification of the model is appropriate as j-statistics is insignificant (Table 3). Cragg-Donald statistics is also insignificant, signifying that the instruments are strong enough for the identification of the model. The variance of the index-put-option as a dependent variable does not have a significant relationship with index-spot and index-futures variances, but has significant relationship with the lag series variance of index-put options. However, in this case, model identification is not appropriate as $\mathbf{j}$-statistics is significant (Table 3), despite having strong instruments (as Cragg-donald statistic is insignificant).

\subsection{Impact of Structural Breaks}

As discussed in Section 3.5, two threshold points are tested for structural breaks. The GMM breakpoint test is deployed to verify structural breaks in this paper. In May 2014, the GMM breakpoint test was significant only with variance of the index-call-option as a dependent variable out of four specifications. The second structural break (November 2016) is significant with all the four variances as dependent variables undertaken in the study (Table 3). This implies that May 2014 was not felt as a major structural break for the volatility integration among index-spot, index-future and index-options. However, November 2016 was observed as a structural break as the GMM breakpoint test results are significant for all the four estimated models.

The application of diagnostic tests (J-Statistics and Cragg-donald statistics) in the estimation of all three equations (Equations (1)-(3)) (which is consistent in their estimation) ensures the robustness of the results.

\section{Discussion}

The first hypothesis that the volatility of spot, futures and options have a long-term association is partially accepted. The volatility of the index-spot market has a significant relationship with the volatility of index-futures but does not have a significant relationship with the volatility of index-options. In addition to this, the volatility of index-futures has a significant association with the volatility of 
index-spot, but not with the volatility of index-options. However, the volatility of index-options does not have a significant relationship with the volatilities of index-spot and index-futures.

The second hypothesis, regarding structural breaks, is true for one of the two proposed structural breaks. The first break proposed in May 2014, is not significant for the volatility of index-spot and index-futures but it is significant for index-options markets; whereas the second proposed break in November 2016 is significant for volatility in all the three markets.

This paper deliberates two-pronged managerial and policy implications. The primary implication is from the investors' point of view. Investors in India invest less in options than futures. By an estimate in 2015, investment in terms of value in Nifty-50 index-futures was 11.65 times the investments in Nifty-50 index options (NSE 2015). The findings of this paper support the distinction between futures and options markets regarding the integration of volatility in both the markets with respect to spot markets. The main aim of investing in the derivatives market is to hedge (Shiu and Moles 2010). The options market can serve the purpose of hedging better than the futures market. The findings of the current paper suggest that volatility in the options market is not integrated with the volatility in the spot market whereas volatility in the futures market is associated with the spot market (Table 3).

This finding brings spot and futures markets to the same platform; however, options remain away from this integration of volatility between spot and futures markets. Therefore, it is advisable to investors to get the benefit of the options market for hedging because it behaves differently than spot and futures markets. This has two benefits. Not only will investors be better off in terms of hedging, but the options market will also grow, which is not the present scenario (NSE 2015).

The second implication of the findings is for policy makers. The main concern of policy makers regarding derivative markets is how the derivatives market impacts the spot market. Public opinion regarding the adverse impact of derivatives on spot markets is very strong presently (Tripathi 2014). Responsibility for the negative publicity of derivatives may be due to the levered nature of derivative instruments but governments always find it risky to support the derivatives market. However, this perception about the entire derivatives market can change with the help of findings in this paper. Rather, the options market should be seen differently than the futures market. The reluctance of policy makers for launching options can also be avoided by using the findings of this paper.

Volatility is an important measure for the securities market. The same set of securities are traded in all three markets, viz. in spot, futures and options markets. Therefore, volatility in the three markets is expected to be integrated.

In this paper, a significant association is found between the volatilities of index-spot and index-futures markets (of financial securities markets). However, volatility in the index-option market does not have any significant association with the volatility of index-spot and index-futures markets (the results are derived by using financial securities only).

Moreover, out of the two structural breaks undertaken in the study, the second structural break — change of the guard in USA and demonetization in India during November 2016-is significant in all three markets with respect to the other two markets in volatility modeling.

The present study has two main limitations. First, this study does not use control variables to neutralize the impact of other factors aside from the volatility in the three markets. Second, as discussed earlier, this study could not explain the reason for the non-association of the volatility of index-options with the volatility of the other two markets (spot and future markets). Both the limitations are future areas of study on this topic.

\section{Conclusions}

Volatility in the options market is not integrated with the volatility of the other two markets studied here (spot and futures). This finding is unique as the authors did not find any earlier research referring to the integration of volatility in the three markets. The volatility in the options market behaving differently can be explained. The return function of the option is non-linear, whereas futures have a linear return function. This may be the reason for the different volatility behavior of the options 
market as compared to the futures market. Additionally, in the options market, investors have to pay a price to take a long position, whereas in the futures market nothing is paid to take a position (a margin payment is the security money paid by futures investors, and not the price to be paid to take a position in futures markets). Payments (for option premium) can also be the reason for the different behavior of the options market as compared to the futures market. Both the explanations need empirical scrutiny which could be an area for future research.

Moreover, the authors also did not find any other study on volatility covering both the structural breaks undertaken in the study. However, May 2014 is not found to be a significant structural break in spot and futures market volatility. This can be due to the fact that the reach of the political change of the landscape in India in May 2014 did not have much bearing on the securities market. On the contrary in November 2016, when demonetization was executed in India and a change of guard took place in the US, it had a significant impact on the volatility of all the three markets. This raises the point that demonetization was a statistically significant move by the Government of India regarding the securities market, and that the change of guard in the US was similarly significant.

Shenbagaraman (2003) highlights no significant impact of the introduction of index-futures and index-options on index-spot volatility. However, the futures market was able to reduce the day-of-the-week effect of the index-spot market. Moreover, futures were also able to change the sensitivity of Indian index-spot returns with respect to the index-spot returns of the US stock market. Though our study discusses the volatility integration in three markets, the findings of Shenbagaraman (2003) support the results of our study; that the volatility of the spot market integrates with the volatility of fthe utures market, but not with the volatility of the options market.

Sogiakas and Karathanassis (2015) show that within sub-periods of their study, when the market was efficient, the futures market shows evidence of price discovery of spot rates. These findings support the results of our study, that the futures market impacts spot markets. Sogiakas and Karathanassis (2015) have not studied volatility integration in both the markets as it is done in the present study.

Wang and Chen (2007) examine the integration of three markets (spot, futures and options). The Wang and Chen (2007) study does not focus on volatility, rather studying the dynamic association among the three markets. However, simultaneity is considered as an obvious choice, which also has the support of the literature, as discussed earlier as well in the current paper (see Wang and Chen 2007, for evidences on the support of simultaneity in the three markets). Simultaneity is found in the volatility of index-option markets with respect to the volatility of index-spot and index-futures markets. However, this paper does not find evidence of simultaneity in index-spot (with respect to index-future and index-options) and index-futures markets (with respect to index-spot and index-option markets). Other than simultaneity, volatility transmission is also highlighted by Wang and Chen (2007) but the results were inconclusive for volatility transmission. Contrary to Wang and Chen (2007), our study solely focuses on volatility integration and finds that simultaneity is present in index-options (both call and put) with respect to the variances of index-spot and index-futures.

To the best of the authors' knowledge, there are no other studies covering the integration of the volatility in the three markets. The research findings of the paper, that the options market behaves differently as compared to the futures market, is also not explored in earlier studies. Moreover, a discussion of structural breaks with respect to volatility studies of the three markets is also a novel contribution of the current study.

Author Contributions: Both the authors have contributed in conceptualization on the topic, literature review, data analysis and preparing the draft for the paper.

Funding: The research is self-sponsored and no external funding.

Conflicts of Interest: The authors declare no conflict of interest. 


\section{References}

Andersen, Torben G., and Tim Bollerslev. 1998. Answering the skeptics: Yes, standard volatility models do provide accurate forecasts. International Economic Review 39: 885-905. [CrossRef]

Atilgan, Yigit, K. Ozgur Demirtas, and Koray D. Simsek. 2016. Derivative markets in emerging economies: A survey. International Review of Economics E Finance 42: 88-102.

Bae, Sung C., Taek Hp Kwon, and Jong Won Park. 2004. Futures trading, spot market volatility, and market efficiency: The case of the Korean index futures markets. Journal of Futures Markets 24: 1195-228. [CrossRef]

Bakshi, Gurdip, Charles Cao, and Zhiwu Chen. 1997. Empirical performance of alternative option pricing models. The Journal of Finance 52: 2003-49. [CrossRef]

Banerjee, Anindya, and Giovanni Urga. 2005. Modelling structural breaks, long memory and stock market volatility: an overview. Journal of Econometrics 129: 1-34. [CrossRef]

Bansal, Ravi, Dana Kiku, Ivan Shaliastovich, and Amir Yaron. 2014. Volatility, the macroeconomy, and asset prices. The Journal of Finance 69: 2471-511. [CrossRef]

Bessembinder, Hendrik, and Paul J. Seguin. 1992. Futures-Trading Activity and Stock Price Volatility. The Journal of Finance 47: 2015-34. [CrossRef]

Bollen, Nicolas P., and Robert E. Whaley. 2004. Does net buying pressure affect the shape of implied volatility functions? The Journal of Finance 59: 711-53. [CrossRef]

Bologna, Pierluigi. 2000. Index Futures Activity and Stock Market Volatility: An Empirical Analysis of the Italian Stock Exchange. Giornale degli Economisti e Annali di Economia 59: 49-86.

Bologna, Pierluigi, and Laura Cavallo. 2002. Does the introduction of stock index futures effectively reduce stock market volatility? Is the 'futures effect' immediate? Evidence from the Italian stock exchange using GARCH. Applied Financial Economics 12: 183-92. [CrossRef]

Chakravarty, Sugato, Huseyin Gulen, and Stewart Mayhew. 2004. Informed trading in stock and option markets. The Journal of Finance 59: 1235-57. [CrossRef]

Chan, Kalok. 1993. Imperfect information and cross-autocorrelation among stock prices. The Journal of Finance 48: 1211-30. [CrossRef]

Chan, Leo, and Donald Lien. 2006. Are options redundant? Further evidence from currency futures markets. International Review of Financial Analysis 15: 179-88. [CrossRef]

Chan, Kalok, K. C. Chan, and G. Andrew Karolyi. 1991. Intraday volatility in the stock index and stock index futures markets. The Review of Financial Studies 4: 657-84. [CrossRef]

Chan, Kalok, Y. Peter Chung, and Wai-Ming Fong. 2002. The informational role of stock and option volume. The Review of Financial Studies 15: 1049-75. [CrossRef]

Chan, Brian, Andy Cheng, and Alfred Ma. 2018. Stock Market Volatility and Trading Volume: A Special Case in Hong Kong With Stock Connect Turnover. Journal of Risk and Financial Management 11: 76. [CrossRef]

Chang, Chuang-Chang, Pei-Fang Hsieh, and Yaw-Huei Wang. 2010. Information content of options trading volume for future volatility: Evidence from the Taiwan options market. Journal of Banking and Finance 34: 174-83. [CrossRef]

Chang, Chia-Lin, Michael McAleer, and Guangdong Zuo. 2017. Volatility spillovers and causality of carbon emissions, oil and coal spot and futures for the EU and USA. Sustainability 9: 1789. [CrossRef]

Chang, Chia-Lin, Michael McAleer, and Chien-Hsun Wang. 2018. An econometric analysis of ETF and ETF futures in financial and energy markets using generated regressors. International Journal of Financial Studies 6: 1-24.

Chen, Yu-Lun, and Yin-Feng Gau. 2009. Tick Sizes and Relative Rates of Price Discovery in Stock, Futures, and Options Markets: Evidence from the Taiwan Stock Exchange. Journal of Futures Markets 29: 74-93. [CrossRef]

Chen, Chao-Chun, and Shih-Hua Wang. 2017. Net Buying Pressure and Option Informed Trading. Journal of Futures Markets 37: 238-59. [CrossRef]

Cheng, Louis T. W., Joseph K. W. Fung, and Kam C. Chan. 2000. Pricing dynamics of index options and index futures in Hong Kong before and during the Asian financial crisis. Journal of Futures Markets 20: 145-66. [CrossRef]

Chiang, Raymond, and Wai-Ming Fong. 2001. Relative informational efficiency of cash, futures, and options markets: The case of an emerging market. Journal of Banking and Finance 25: 355-75. [CrossRef]

Darrat, Ali F., Shafiqur Rahman, and Maosen Zhong. 2002. On the Role of Futures Trading in Spot Market Fluctuations: Perpetrator of Volatility or Victim of Regret? Journal of Financial Research 25: 431-44. [CrossRef] 
De Davide, Gaetano. 2018. Forecast Combinations in the Presence of Structural Breaks: Evidence from US Equity Markets. Mathematics 6: 34.

Debasish, Sathya. 2009. An econometric analysis of the lead-lag relationship between India's NSE Nifty and its derivative contracts. The Journal of Risk Finance 10: 350-64. [CrossRef]

Dickey, David A., and Wayne A. Fuller. 1979. Distribution of the estimators for autoregressive time series with a unit root. Journal of the American Statistical Association 74: 427-31.

Dickey, David A., and Wayne A. Fuller. 1981. Likelihood ratio statistics for autoregressive time series with a unit root. Econometrica: Journal of the Econometric Society 49: 1057-72. [CrossRef]

Draper, Paul, and Joseph K. W. Fung. 2002. A Study of Arbitrage Efficiency Between the FTSE-100 Index Futures and Options Contracts. Journal of Futures Markets 22: 31-58. [CrossRef]

Dufour, Jean-Marie, and Eric Ghysels. 1996. Editors' introduction recent developments in the econometrics of structural change. Journal of Econometrics 70: 1-8. [CrossRef]

Edwards, Franklin R. 1988. Does futures trading increase stock market volatiity? Financial Analysts Journal 44: 63-69. [CrossRef]

Fahlenbrach, Rudiger, and Patrik Sandås. 2009. Co-movements of index options and futures quotes. Journal of Empirical Finance 16: 151-63. [CrossRef]

Farkas, Walter, Elise Gourier, Robert Huitema, and Ciprian Necula. 2017. A two-factor cointegrated commodity price model with an application to spread option pricing. Journal of Banking $\mathcal{E}$ Finance 77: 249-68.

Fernandez, Viviana. 2004. Detection of Breakpoints in Volatility. Estudios de Administracion 11: 1-38.

Floros, Christos, and Enrique Salvador. 2016. Volatility, trading volume and open interest in futures markets. International Journal of Managerial Finance 12: 629-53. [CrossRef]

Gabriel, Anton Sorin. 2012. Evaluating the Forecasting Performance of GARCH Models. Evidence from Romania. Procedia-Social and Behavioral Sciences 62: 1006-10. [CrossRef]

Gemmill, Gordon. 1986. The forecasting performance of stock options on the London traded options market. Journal of Business Finance $\mathcal{E}$ Accounting 13: 535-46.

Guo, Hui, and Buhui Qiu. 2014. Options-implied variance and future stock returns. Journal of Banking and Finance 44: 93-113. [CrossRef]

Gwilym, Owain Ap, and Mike Buckle. 2001. The lead-lag relationship between the FTSE100 stock index and its derivative contracts. Applied Financial Economics 11: 385-93. [CrossRef]

Han, Li-Ming, and Lalatendu Misra. 1990. The Relationship between the Volatilities of the S\&P 500 Index and Futures Contracts Implicit in Their Call Option Prices. Journal of Futures Markets 10: 273-85.

He, Ling-Yun, and Wen-Si Xie. 2012. Who has the final say? Market power versus price discovery in China's sugar spot and futures markets. China Agricultural Economic Review 4: 379-90. [CrossRef]

Hentze, Staffan, and Michael J. Seiler. 2000. An Examination of the Lead/Lag Relationship between the Option Market and the Stock Market: Where Do We Stand? Quarterly Journal of Business and Economics 39: 35-48.

Hodgson, Allan, and Des Nicholls. 1991. The impact of index futures markets on Australian sharemarket volatility. Journal of Business Finance \& Accounting 18: 267-80.

$\mathrm{Hu}$, Jianfeng. 2014. Does option trading convey stock price information? Journal of Financial Economics 111: 625-45. [CrossRef]

Huo, Rui, and Abdullahi D. Ahmed. 2017. Relationships between Chinese stock market and its index futures market: Evaluating the impact of QFII scheme. Research in International Business and Finance 44: 135-52. [CrossRef]

Jagannathan, Ravi, Georgios Skoulakis, and Zhenyu Wang. 2002. Generalized methods of moments: Applications in finance. Journal of Business $\mathcal{E}$ Economic Statistics 20: 470-81.

Jarque, Carlos M., and Anil K. Bera. 1980. Efficient tests for normality, homoscedasticity and serial independence of regression residuals. Economics Letters 6: 255-59. [CrossRef]

Jong, Frank De, and Monique W. Donders. 1998. Intraday lead-lag relationships between the futures-, options and stock market. Review of Finance 1: 337-59. [CrossRef]

Judge, Amrit, and Tipprapa Reancharoen. 2014. An empirical examination of the lead-lag relationship between spot and futures markets: Evidence from Thailand. Pacific-Basin Finance Journal 29: 335-58. [CrossRef]

Kang, Jangkoo, Chang Joo Lee, and Soonhee Lee. 2006. An empirical investigation of the lead-lag relations of returns and volatilities among the KOSPI200 spot, futures and options markets and their explanations. Journal of Emerging Market Finance 5: 235-61. [CrossRef] 
Karmakar, Madhusudan. 2005. Modeling conditional volatility of the Indian stock markets. Vikalpa 30: 21-38. [CrossRef]

Kasman, Adnan, and Saadet Kasman. 2008. The impact of futures trading on volatility of the underlying asset in the Turkish stock market. Physica A: Statistical Mechanics and its Applications 387: 2837-45. [CrossRef]

Kavussanos, Manolis G., and Ilias D. Visvikis. 2004. Market interactions in returns and volatilities between spot and forward shipping freight markets. Journal of Banking E Finance 28: 2015-49.

Kavussanos, Manolis G., Ilias D. Visvikis, and Dimitris N. Dimitrakopoulos. 2014. Economic spillovers between related derivatives markets: The case of commodity and freight markets. Transportation Research Part E: Logistics and Transportation Review 68: 79-102. [CrossRef]

Kim, Jun Sik, and Doojin Ryu. 2014. Intraday price dynamics in spot and derivatives markets. Physica A: Statistical Mechanics and its Applications 394: 247-53. [CrossRef]

Kleidon, Allan W., and Robert E. Whaley. 1992. One Market? Stocks, Futures, and Options During October 1987. The Journal of Finance 47: 851-77. [CrossRef]

Koutmos, Gregory, and Michael Tucker. 1996. Temporal Relationships and Dynamic Interactions between Spot and Futures Stock Markets. Journal of Futures Markets 16: 55-69. [CrossRef]

Larcker, David F., and Tjomme O. Rusticus. 2010. On the use of instrumental variables in accounting research. Journal of Accounting and Economics 49: 186-205. [CrossRef]

Li, Ming-Yuan Leon. 2008. Clarifying the dynamics of the relationship between option and stock markets using the threshold vector error correction model. Mathematics and Computers in Simulation 79: 511-20. [CrossRef]

Lin, William T., Shih-Chuan Tsai, Zhenlong Zheng, and Shuai Qiao. 2017. Does options trading convey information on futures prices? North American Journal of Economics and Finance 39: 182-96. [CrossRef]

Malhotra, Meenakshi, and Dinesh Kumar Sharma. 2016. Volatility dynamics in oil and oilseeds spot and futures market in India. Vikalpa 41: 132-48. [CrossRef]

Morales, Lucia, and Esmeralda Gassie-Falzone. 2014. Structural breaks and financial volatility: lessons from the BRIC countries. Economics, Management and Financial Markets 9: 67-91.

Morales-Zumaquero, Amalia, and Simon Sosvilla-Rivero. 2010. Structural breaks in volatility: Evidence for the OECD and non-OECD real exchange rates. Journal of International Money and Finance 29: 139-68. [CrossRef]

Ni, Sophie X, Jun Pan, and Allen M. Poteshman. 2008. Volatility information trading in the option market. The Journal of Finance 63: 1059-91. [CrossRef]

NSE. 2015. A Review of Indian Securities Market. National Stock Exchange India Limited. Available online: https://www.nseindia.com/education/content/prs_publications.htm (accessed on 15 March 2018).

Pan, Jun, and Allen M. Poteshman. 2006. The information in option volume for future stock prices. The Review of Financial Studies 19: 871-908. [CrossRef]

Phillips, Peter C. B., and Pierre Perron. 1988. Testing for a unit root in time series regression. Biometrika 75: 335-346. [CrossRef]

Pericli, Andreas, and Gregory Koutmos. 1997. Index futures and options and stock market volatility. Journal of Futures Markets 17: 957-74. [CrossRef]

Pok, Wee Ching, and Sunil Poshakwale. 2004. The impact of the introduction of futures contracts on the spot market volatility: The case of Kuala Lumpur Stock Exchange. Applied Financial Economics 14: 143-54. [CrossRef]

Qin, Fengming, Junru Zhang, and Zhaoyong Zhang. 2018. RMB exchange rates and volatility spillover across financial markets in China and Japan. Risks 6: 120. [CrossRef]

Rastogi, Shailesh, and Vinay K. Srivastava. 2011. Comparative study of conditional volatility of Indian and US stock markets using GARCH $(1,1)$ model. Asia Pacific Business Review 7: 92-101. [CrossRef]

Ryu, Doojin. 2012. Implied volatility index of KOSPI200: Information contents and properties. Emerging Markets Finance and Trade 48: 24-39. [CrossRef]

Sarwar, Ghulam. 2005. The informational role of option trading volume in equity index options markets. Review of Quantitative Finance and Accounting 24: 159-76. [CrossRef]

Shenbagaraman, Premalata. 2003. Do Futures and Options Trading Increase Stock Market Volatility? NSE Research Initiative Paper 71. Mumbai: NSE.

Shiu, Yung-Ming, and Peter Moles. 2010. What motivates banks to use derivatives: evidence from Taiwan. The Journal of Derivatives Summer 17: 67-78. [CrossRef] 
Silverio, Renan, and Alexandre Szklo. 2012. The effect of the financial sector on the evolution of oil prices: Analysis of the contribution of the futures market to the price discovery process in the WTI spot market. Energy Economics 34: 1799-808. [CrossRef]

Sogiakas, Vasilios, and George Karathanassis. 2015. Informational efficiency and spurious spillover effects between spot and derivatives markets. Global Finance Journal 27: 46-72. [CrossRef]

Stephan, Jens A., and Robert E. Whaley. 1990. Intraday price change and trading volume relations in the stock and stock option markets. The Journal of Finance 45: 191-220. [CrossRef]

Szu, Wen-Ming, Ming-Chun Wang, and Wan-Ru Yang. 2011. The determinants of exchange settlement practices and the implication of volatility smile: Evidence from the Taiwan Futures Exchange. International Review of Economics \& Finance 20: 826-38.

Tokat, Ekin, and Hakki Arda Tokat. 2010. Shock and Volatility Transmission in the Futures and Spot Markets: Evidence from Turkish Markets. Emerging Markets Finance and Trade 46: 92-104. [CrossRef]

Tripathi, Gunjan. 2014. An Empirical Investigation of Investors Perception towards Derivative Trading. Global Journal of Finance and Management 6: 99-104.

Turkington, Joshua, and David Walsh. 2000. Informed traders and their market preference: Empirical evidence from prices and volumes of options and stock. Pacific-Basin Finance Journal 8: 559-85. [CrossRef]

Wang, Kai-Li, and Mei-Ling Chen. 2007. The dynamics in the spot, futures, and call options with basis asymmetries: An intraday analysis in a generalized multivariate GARCH-M MSKST framework. Review of Quantitative Finance and Accounting 29: 371-94. [CrossRef]

Wang, Yudong, and Chongfeng $\mathrm{Wu}$. 2013. Are crude oil spot and futures prices cointegrated? Not always! Economic Modelling 33: 641-50. [CrossRef]

Xie, Shiqing, and Taiping Mo. 2014. Index Futures Trading and Stock Market Volatility in China: A Difference-inDifference Approach. Journal of Futures Markets 34: 282-97. [CrossRef]

$\mathrm{Yu}$, Shang-Wu. 2001. Index futures trading and spot price volatility. Applied Economics Letters 8: 183-86. [CrossRef]

(C) 2019 by the authors. Licensee MDPI, Basel, Switzerland. This article is an open access article distributed under the terms and conditions of the Creative Commons Attribution (CC BY) license (http://creativecommons.org/licenses/by/4.0/). 